International Journal of Innovation Management

Vol. 6, No. 2 (June 2002) pp. 131-161

(C) Imperial College Press

\title{
RESEARCH AND DEVELOPMENT IN RUSSIA AND ITS ROLE IN NATIONAL COMPETITIVENESS
}

\author{
SVETLANA YURIEVNA OGLOBINA \\ International Economy Department \\ Irkutsk State Academy of Economics \\ 11, Lenin Street \\ 664015 Irkutsk, Russia
}

\author{
ANA PAULA FARIA and CARLOS CABRAL-CARDOSO* \\ School of Economics and Management \\ University of Minho, Gualtar \\ 4710-057 Braga, Portugal \\ *ccabral@eeg.uminho.pt
}

Received 1 March 2001

Revised 18 July 2002

Accepted 31 July 2002

\begin{abstract}
There is now a large body of literature showing that research and development (R\&D) activities have a major impact in the economy, leading to increases in productivity, competitiveness and economic growth. Using the concept of national innovation system this paper is an attempt to understand the current status of Russian technological development and the role R\&D might play in the transition from a command economy to a free-market economy. Despite the effects of a declining $R \& D$ workforce and continuing underfunding of $R \& D$ institutions, a considerable $R \& D$ potential is still in place. The major barriers for its effective contribution to economic and business recovery are discussed in detail. Some innovation and R\&D policy implications at both central and regional levels are also drawn.
\end{abstract}

Keywords: Russia; national innovation systems; R\&D potential; R\&D workforce; transitional economies.

\section{Introduction}

The impact of technological change on competitiveness and economic growth has been recognised as a major feature of the world economy in the last four decades. It affects a country's performance in several and complex ways, and is 
related to the degree of research intensity of the economy, the cumulative nature of technological knowledge, the distinctive patterns in the different sectors of economic activities, and the characteristics of the national innovation systems.

Advanced economies have become more knowledge-intensive. A considerable number of empirical studies (Archibugi \& Pianta, 1993) found that international competitiveness, productivity, and rates of growth are linked to the ability to innovate successfully. There is a large body of literature, including cross-country empirical studies, demonstrating that R\&D makes an important contribution to the growth of firms, industries and countries (Korres, 1996). For instance, the studies by Abramovitz (1991) and Fagerberg (1987) have suggested that there is a close correlation between technological development and productivity. Dosi, Pavitt \& Soete (1990), on the other hand, found that the patent index (defined as the cumulative number of patents registered by each country in the US) is correlated with labour productivity. Verspagen (1994) distinguished between business and non-business $R \& D$ and found that the growth of total $R \& D$ business stock is a positive and significant determinant of GDP growth. Also, Gittelman \& Wolff (1995) found that R\&D activities might partly explain crossnational differences in growth among advanced countries.

While the relationship between technology, productivity and international competitiveness has been the focus of studies for most developed nations, the case of Eastern Europe remains largely unexplored (Audretsch, 1993). Thus, the purpose of this paper is to describe the innovation developments in Russia during the 1990s. Despite the many negative aspects of the downsizing policies conducted in the Russian R\&D establishment, which led to the loss of many scientific jobs and some R\&D capabilities, Russian R\&D still has potential to contribute to the national economic growth. Furthermore, a strong innovation system is important for the future of the Russian economy and its international competitiveness. This paper attempts to present data and discuss some conditions about the contemporary situation of research and technological development in Russia. The focus of the discussion will be on the national innovation system and some aspects of R\&D policy implications.

The first section of this paper presents some basic definitions relevant to the concept of innovation, and explores in particular the concept of national innovation system. The second section analyses some empirical data and national R\&D indicators in Russia. The third section identifies some specific obstacles to the innovation process in Russian companies in the current transitional economy and discusses some of its policy implications. Finally, the paper draws some conclusions about the current status of Russian $R \& D$ and its role in national competitiveness. 


\section{Systems of Innovation}

In order to understand the specific problems of the evaluation of scientific and technological development, it is useful to present some concepts related to the theory of systems of innovation. Views about the character of the innovation process have changed considerably in recent years. Both the traditional Schumpeterian and the linear product cycle model have been found inadequate. Innovation is neither an exclusive internal activity of firms in order to achieve monopolistic advantages (Schumpeter, 1934) nor does it follow a mechanistic sequence from research to production and to the market, in which research is the main driving force, as the linear (science-push) model and product cycle theory argue. Increasingly, innovation is regarded as an evolutionary, non-linear and interactive process between the firm and its environment (Dosi, 1988).

The concept of non-linearity (market-driven model) implies that innovation is stimulated and influenced by many actors and sources of information, both inside and outside the firm. It is not only determined by scientists and engineers working in $\mathrm{R} \& \mathrm{D}$ or by the top-management. In addition, there are interactions feeding back the experience of production, marketing and customers into earlier phases of the innovation process. The interactivity of the innovation process refers to the internal collaboration between several departments of a company (R\&D, production, marketing, distribution, etc.) as well as to external co-operations with other firms (especially with customers and suppliers), knowledge providers (like universities and technology centres), finance, training, and public administration (Kaufmann \& Tödtling, 2000). These are all contributing to the firms' capacity to innovate.

To understand the process referred to above, the concept of system of innovation has been proposed in the literature. The following propositions have been brought forward serving its theoretical background (Tödtling \& Kaufmann, 1999):

- Innovation is considered as a non-linear and interdependent process (Dosi, 1988). Besides $R \& D$, it may have various starting points and often these are clients or marketing and distribution functions. Then, there are interdependencies and feedback loops to be observed. There is increasing interdependence within firms (e.g. between distribution, marketing, $\mathrm{R} \& \mathrm{D}$, production) as well as between firms (e.g. relations to customers and suppliers) and with other organisations. To a high degree these interdependencies go beyond market relations and occur in "networks" (Pratt, 1997; Autio, 1998; Tödtling \& Kaufmann, 1999; Koschatzky \& Sternberg, 2000) that are more stable and trust based relations allowing common learning (Asheim, 1996). 
- Knowledge in a broad sense is becoming more important. It is relevant not just at the beginning (in the form of $\mathrm{R} \& \mathrm{D}$ ) but also throughout the whole innovation process and there are various forms of knowledge involved (Lundvall, 1998). On the one hand, there is "codified knowledge", which can easily be transmitted through various channels of communication and does not require spatial proximity for exchange. On the other hand, there is "tacit knowledge", which is embodied in the labour force, in human skills, or in organisational routines. Tacit knowledge is more tied to particular firms, social groups and places and it can only be accessed through direct face-to-face communication or through joint activities (e.g. co-operative R\&D projects).

- Uncertainties (with respect to technology and markets) are a main feature of the innovation process as well as appropriability problems (Kay, 1988). It is only through institutions that these problems can partly be overcome. Institutions in the sense of Hodgson (1988) include "rules of the game" (e.g. patent laws), organisations (e.g. technology transfer agencies) as well as behavioural values and routines (e.g. attitudes towards change and risk). Institutions fulfil several functions in the innovation process (Edquist, 1997). First, they reduce uncertainties, e.g. through standards or the provision of information. Second, they regulate conflict between various actors and give rules for co-operation. Third, they provide incentives for innovation by granting economic and other rewards (e.g. through the protection of patents for a certain time).

- The institutional setting of a region and a country, thus, is highly relevant for the stimulation and implementation of innovations. Such a setting is strongly shaped by the respective governance model, which includes the actions of public, semi-public and private actors and organisations. In the field of innovation, governance is becoming increasingly multilevel and therefore the result of a complex interplay between local, regional, national and supra-national actors and organisations (Cooke et al., 1998).

- Other types of institution, allowing firms to cope with uncertainty, are routines. For the innovation process this has been pointed out by Nelson \& Winter (1977) and Dosi (1988). Routines with respect to search, screening and selection of information give stability and direction to the innovation process by bringing firms on specific technology paths or trajectories. Once routines are shared among firms in a specific region they may constitute a regional trajectory, i.e. a specific pattern of finding technological solutions and of innovating (Saxenian, 1994). Such trajectories may for a while support the innovation process through the accumulation of specific knowledge and the building up of competencies. However, these views may become an obstacle to adjustment once technologies and economic conditions change. 
The innovation systems approach rests on these propositions and is a tool to analyse interdependencies in the innovation process. According to Lundvall (1992), an innovation system is constituted by actors and elements, which interact in the production, diffusion and the use of economically useful knowledge. It is a social system in the sense that interactive learning as a social activity is in the centre, and it is also a dynamic system where "the elements either reinforce each other in promoting processes of learning and innovation or, conversely, combine into constellations blocking such processes" (Lundvall, 1992: 2).

The key to further theoretical developments around the innovation process is to understand better the role of innovation system in the economy. In the following section, the concept of national innovation system and its application as a framework for this study is briefly discussed.

\section{National innovation system}

At the country level, the range of institutions that contribute to innovation and the linkages among them comprise the national innovation system. Nationally, the innovation process takes place within this system and reflects the behaviour of its components and the nature of the links between them. The national innovation system is a very useful concept for understanding how technical advance occurs in the modern world, and why specific features of the innovation process differ from one country to another. It can be also regarded as a tool for analysing economic development and economic growth.

The concept "national innovation system" (NIS) was made explicit in a number of contributions in the second half of the 1980s. When the NIS concept first appeared in the literature it reflected new developments in innovation research. The most fundamental new insight of innovation studies in the 1980s was that innovation is an interactive process where agents and organisations communicate, co-operate and establish long-term relationships.

Freeman (1987) was the first who introduced and used the NIS concept to analyse post-war Japanese economic growth. Later, Lundvall (1992) applied it to a broader cross-section of economies. Nelson (1993) showed that innovation systems differ significantly between countries, depending on their economic structure, knowledge base and institutional specificities. Porter (1990) does not explicitly use this concept but his analysis of national competitive advantage is characterised by an approach similar to the NIS literature.

Freeman and Lundvall did not elaborate on the definition of NIS. Such conceptual work was carried out by Niosi et al. (1993), who viewed NIS as interrelated sets of institutional spheres. From the social system perspective, they distinguish different types of links between institutional spheres: 
- Financial flows, initiated by both public and private institutions.

- Legal and policy links, such as intellectual property rules, technical standards, and technology and procurement policy.

- Technological, scientific, and informational flows (both market-driven and those resulting from technological and scientific collaborations).

- Social flows, comprising organisational innovations and human resource flows.

The emphasis of the discussion of Niosi et al. (1993) is very much on the institutional make-up of the NIS, and on links and exchanges between the subsystems that constitute the NIS. They place much emphasis on flows of goods, knowledge, money, skills and other inputs and outputs of innovative processes. The actual interactions between institutions, however, do not feature prominently in their discussion. Instead of discussing single institutions, their discussion is more on what might be called institutional spheres. To simplify, they see institutional antecedents of knowledge, resource and human capital flows, but they do not see the actors that actually generate these flows. Hence, they are not much concerned with what drives institutional actors and their interactions with other actors (Autio, 1998).

Initially, the concept of the innovation systems has been applied to the national level where economists have demonstrated that industrial systems, institutions and technology paths within countries are strongly related. It has been shown that particular research environments, systems of education, finance and regulation shape the innovation process of specific countries to a high degree (Porter, 1990; Nelson, 1993). More recently the systems approach has been extended to a multilevel setting where regional, national, and the supra-national levels play a role. Concerning the regional level there are parallels with concepts such as the "innovative milieu" (Sternberg, 2000) as well as technology districts (UN, 1994). In some cases, these studies have presented themselves as more relevant than analysis at the level of the national system.

We argue that even if the trend toward globalisation and regional integration of innovation activities is stronger, the analysis of innovation systems at the national level is still important for several reasons. First, standard economics is extremely national in its analytical focus. This is true for almost all applied research in the field including the analyses by international organisations such as OECD, the World Bank, etc. Analytical work on aggregates for multinational regions, or at the level of the global economy, is still marginal and exceptional. Second, the dominating debate regarding economic policy, including monetary and fiscal policy, as well as labour market and social policy refers to the national level. Finally, some experts have challenged the national perspective with a reference to the process of globalisation and the process of regional integration, 
especially the formation of the European Union (Lundvall, 1998). It is worth noting that this is not an argument against alternative analyses of innovation systems at the level of intra- or transnational regions or at the level of technologies, sectors or firms. On the contrary, one can understand how national systems develop only by breaking them down into sub-systems.

The literature on innovation systems is diverse, and different scholars have approached the phenomenon along various ways. There is not one standard reference, and there are many interpretations of the concept among leading scholars. In this paper, two main approaches to national innovation systems described in the literature are presented. One approach has been developed by Freeman (1987) and takes as its starting point the fact that important parts of the innovation process are not based only on search activities related to science and technology, but also on routine-based learning-by-doing, -using and -interacting. According to this approach, the prevailing economic structure and the institutional set-up are at the core of the NIS analysis. The policy implications relate to S\&T policy as well as to policies of human resource development, and to the institutional set up of markets for labour and finance.

The other approach tends to regard the NIS concept as a follow-up and a broadening of earlier analyses of national science systems and national technology policies. It is typical to authors, especially coming from the U.S. tradition (Mowery \& Oxley, 1995). To them, the key issue is to map indicators of national specialisation and performance regarding innovation, R\&D efforts and science and technology. The policy issues raised are typically related almost exclusively to S\&T policy (Lundvall, 1998). Also, recently some authors made a major effort to analyse similar features of national innovation systems and construct some typologies. For example, Boyer, Amable, and Bane (Lundvall, 1999) group 12 OECD countries by using a large number of indicators in four different types of national innovation systems. As a result, national systems of innovation can be classified as market-based (US, UK, Australia, and Canada), social democrat (Sweden, Norway, and Finland), meso-corporatist (Japan) and public institutions-based (Belgium, France, Germany, and the Netherlands).

The need for a deeper understanding of the essence, regularities and specifics of evolution of innovative systems became more relevant since the late 1980s. Despite the obvious progress that has been made in this area, there are still many blank spaces in the theory of innovation. That makes it difficult to evaluate innovative activity, its influence on economic evolution, and the ability of corporations and countries to compete and to regulate this sphere at the national and intergovernmental levels. These blank spaces include indicators of innovative activity. The existing system of indicators does not reflect even those processes that are taking place in a stable economy, to say nothing of a transitional-type 
economy (Gaponenko, 1997). The following section attempts to introduce some trends and problems in the transformation of the innovation system in Russia and assess her R\&D potential.

\section{The Russian R\&D Potential}

Russia entered the $20^{\text {th }}$ century with a powerful scientific and relatively weak technological potential. During the 1930-1970 period, the Soviet Union created a scientific and a technological basis for a national industrial complex at the highest world level. According to reports of the Soviet Academy of Sciences (Varshavski, 1998) and the US National Council for Science and the Environment (NCSE, 1998), toward the end of the Soviet era the Soviet Union was comparable to the US in many fields of science. That was particularly the case in several areas of basic science and in a few areas of applied science (Varshavski, 1998). Table 1 shows that before 1990 different indicators of R\&D intensity in the Soviet Union were comparable to the ones in OECD countries such as France and the UK. Its gross domestic expenditure on R\&D (GERD) volume was about half the one in Germany, one-third of the Japanese and one-eighth of the US.

However, the Soviet R\&D system was weaker than developed countries in most areas of experimental science. This was largely due to the prestige historically associated with theoretical science and mathematics in the Soviet Union, but also because of the lack of adequate scientific equipment. Throughout this period, scientific and technological development had a one-side, selective character (Yakovets, 1994). It contributed significantly to the status of the Soviet Union as a military superpower. The Soviet Union was competing with the United States and other developed countries in several areas of military research, considered an elite area of its $R \& D$ establishment such as nuclear and missile systems, tanks, aviation and submarine fleets. A number of non-defence industries closely connected with the military-industrial complex such as the nuclear industry, space exploration and communication, jet aviation, and radio electronics were also relatively developed. Some of these technologies might have never been developed under competitive pressures of a market system. Dyker (2001) calls them "marsupial" technologies as they resulted from the isolation of the Soviet Union. At the same time, most civilian industries (especially consumer-oriented) were based on outdated technological structures and imported equipment.

Russia inherited from the Soviet Union the R\&D system that had a deserved international reputation in certain areas of basic and materials science, defenceoriented and dual-purpose technology (Dyker, 2000). There is an opinion however, that the Soviet R\&D system, once the largest in the world and respected for high achievements in some areas, particularly military $\mathrm{R} \& \mathrm{D}$, was bloated and wasteful. 
Table 1. Selected indicators of R\&D intensity in the Soviet Union and OECD countries in 1990.

\begin{tabular}{|c|c|c|c|c|c|c|}
\hline \multirow[b]{2}{*}{ Country } & \multirow[b]{2}{*}{$\begin{array}{c}\text { GERD US\$ } \\
\text { Million }\end{array}$} & \multirow[b]{2}{*}{$\begin{array}{l}\text { GERD as } \\
\% \text { of GDP }\end{array}$} & \multicolumn{2}{|c|}{$\%$ of GERD } & \multicolumn{2}{|c|}{ Total R\&D Personnel } \\
\hline & & & $\begin{array}{c}\text { Financed by } \\
\text { Industry }\end{array}$ & $\begin{array}{l}\text { Financed by } \\
\text { Government }\end{array}$ & $\begin{array}{l}\text { Full-Time } \\
\text { Equivalent }\end{array}$ & $\begin{array}{l}\text { Per Thousand } \\
\text { Labour Force }\end{array}$ \\
\hline United States & 149255.0 & 2.77 & 50.6 & 47.1 & N/A & N/A \\
\hline Japan & 62865.0 & 2.88 & 77.9 & 16.1 & 749337 & 12.4 \\
\hline Germany & 31585.3 & 2.73 & 62.0 & 35.1 & 431100 & 14.2 \\
\hline France & 23768.4 & 2.42 & 43.5 & 48.3 & 293031 & 12.0 \\
\hline United Kingdom & 20178.3 & 2.22 & 49.5 & 35.8 & $277800^{1}$ & $9.8^{1}$ \\
\hline Soviet Union & $17999.0^{2}$ & 2.03 & $29.0^{3}$ & $62.3^{3}$ & 1943400 & N/A \\
\hline Italy & 11964.3 & 1.30 & 43.7 & 51.5 & 144917 & 5.9 \\
\hline Canada & 7299.3 & 1.44 & 41.3 & 44.3 & $111990^{4}$ & $8.2^{4}$ \\
\hline Netherlands & 4826.8 & 2.06 & 51.1 & 45.1 & 68170 & 9.9 \\
\hline Spain & 3888.8 & 0.85 & 47.4 & 45.1 & 64934 & 4.2 \\
\hline Switzerland $^{5}$ & 3821.9 & 2.86 & 74.5 & 22.6 & 50250 & 14.2 \\
\hline Sweden $^{5}$ & 3662.9 & 2.54 & 58.2 & 38.4 & 54200 & 11.9 \\
\hline Australia & 3153.5 & 1.25 & 41.6 & 54.3 & 64041 & 8.1 \\
\hline Belgium & 2751.5 & 1.69 & 70.4 & 27.6 & 36779 & 9.3 \\
\hline Austria $^{1}$ & 1796.7 & 1.40 & 53.2 & 44.3 & $3084^{5}$ & $6.7^{5}$ \\
\hline Finland & 1541.8 & 1.87 & 62.2 & 35.3 & $28516^{5}$ & $11.0^{5}$ \\
\hline Denmark & 1444.4 & 1.59 & 46.8 & 45.5 & 25800 & 8.9 \\
\hline Norway & 1318.5 & 1.83 & 43.3 & 50.9 & 20271 & 9.5 \\
\hline Turkey & 885.7 & 0.47 & 27.7 & 71.2 & 16375 & 0.8 \\
\hline Portugal & 501.8 & 0.61 & 27.0 & 61.8 & 12043 & 2.5 \\
\hline Ireland & 388.8 & 0.90 & 60.0 & 29.0 & $8592^{1}$ & $6.6^{1}$ \\
\hline Greece $^{5}$ & 336.3 & 0.47 & 19.4 & 68.9 & 9586 & 2.4 \\
\hline Iceland & 43.7 & 1.03 & 23.9 & 65.8 & 1188 & 9.3 \\
\hline
\end{tabular}

Source: OECD/EAS data bank; Centre for Science Research and Statistics. Ministry of Science and Technological Policy of Russian Federation and Russian Academy of Sciences. N/A = not available.

${ }^{1} 1988$

${ }^{2}$ million ECUs

${ }^{3} 1994$

${ }^{4} 1989$

51991

Comparative studies of R\&D investment present Soviet figures disproportionately higher than national income levels would suggest as a direct result of the socialist policies that treated science as a production force (Radosevic \& Auriol, 1999). The R\&D system was, therefore, "oversized and distorted in its pattern of specialisation... (and) structurally extremely ill-suited to the needs of a market economy" (Dyker, 2001: 862). Applied research had traditionally little impact on industry. Therefore, it was sometimes called "non-applied research" (Zon, 
1996: 19). In post-socialist Russia it became evident that a smaller, more efficient R\&D system focused on developing commercial products would be of more benefit to the evolving Russian market economy than the old R\&D system. But a comparative analysis of $R \& D$ indicators after a few years of reforms shows important potential losses.

\section{Restructuring and downsizing the Russian R\&D system}

Since the early 1990s, Russia gradually moved from a command economy toward a free-market economy leading to radical changes in most sectors of Russian society, not least her R\&D system. This restructuring process was driven, to a significant extent, by the deep economic recession, the breakdown of co-operation among regions and republics of the former Soviet Union and the former members of COMECON, a sharp drop in imports of modern technology and materials, a significant decline in industrial outputs and a decreasing demand on hightechnology products and activities.

After the collapse of the old system, Russia has been through a prolonged financial and economic crisis, the end of which is not yet in sight. During this process sectors that were traditionally dependent on state funding, such as the military sector, and $R \& D$ and social services, saw the volumes of state donations greatly reduced (Tikhomirov, 2000). As a result, R\&D investment has fallen dramatically and a strong downsizing of the Russian R\&D system has taken place. Table 2 sets out some Russian R\&D indicators since 1989. As it shows, expenditure on R\&D as a proportion of GDP was cut by nearly 50\% in the 1990 2001 period. In the context of resolutely negative rates of growth of GDP, the cuts have been sharper in real prices with only a modest recovery since 1999. In current 2001 prices, GERD was about 105.2 trillion rubbles. But due to high inflation in Russia, GERD in constant 1989 rubbles was only about 4.17 billion rubbles, that is, a decrease of about $61.7 \%$.

Some estimates show that by the end of the 1990s, Russian R\&D spending had dropped almost four times and went back to post-war levels. As a result, the Russian GERD was at the level of Portugal, Austria, Egypt, Poland, India and other countries of comparable small science potential (Gokhberg, 1998). Such a dramatic reduction in $R \& D$ investment was due to both decreasing percentages of GDP being devoted to R\&D (from about $2 \%$ in 1990 to about half that figure a decade later) and the decreasing of GDP itself. In accordance with the data of the Russian State Statistics Committee, the GDP in 1997 has decreased to about 40 per cent of 1989 figures. This reduction is explained largely by falling domestic demand on investment into fixed capital, on state consumption, and, particularly, on real income and consumption of the population in Russia (RIE, 1999). 
Table 2. Selected Input Russian Research and Development indicators (1989-2001).

\begin{tabular}{|c|c|c|c|c|c|c|}
\hline \multirow{3}{*}{ Years } & & GERD & \multirow{3}{*}{$\%$ of GDP } & \multirow{3}{*}{$\begin{array}{c}\text { GERD Financed by } \\
\text { Government as a } \% \\
\text { of Total Budget }\end{array}$} & \multirow{3}{*}{$\begin{array}{c}\text { Scientific Degrees } \\
\text { Awarded (Doctoral } \\
\text { Degrees) }\end{array}$} & \multirow{2}{*}{$\begin{array}{l}\text { National R\&D } \\
\text { Personnel } \\
\text { (Researchers and } \\
\text { Technicians) }\end{array}$} \\
\hline & $\begin{array}{c}\text { Constant } \\
1989 \\
\text { Rubles }\end{array}$ & $\begin{array}{l}\text { Current } \\
\text { Rubles }\end{array}$ & & & & \\
\hline & \multicolumn{2}{|c|}{ Billions } & & & & Thousands \\
\hline 1989 & 10.90 & 10.90 & N/A & N/A & N/A & $\begin{array}{l}2215.6 \\
(1389.3)\end{array}$ \\
\hline 1990 & 10.898 & 13.1 & 2.03 & 7.43 & N/A & $\begin{array}{c}1943.3 \\
(1227.4)\end{array}$ \\
\hline 1991 & 7.24 & 20.0 & 1.43 & 7.43 & N/A & $\begin{array}{r}1677.8 \\
(878.5)\end{array}$ \\
\hline 1992 & 3.23 & 140.6 & 0.74 & 2.43 & $\begin{array}{l}128.8 \\
(17.4)\end{array}$ & $\begin{array}{c}1532.6 \\
(804.0)\end{array}$ \\
\hline 1993 & 3.06 & 1317.2 & 0.77 & 4.56 & $\begin{array}{l}123.4 \\
(18.1)\end{array}$ & $\begin{array}{c}1315.0 \\
(644.9)\end{array}$ \\
\hline 1994 & 2.93 & 5146.1 & 0.84 & 1.66 & $\begin{array}{l}115.4 \\
(18.1)\end{array}$ & $\begin{array}{c}1106.3 \\
(525.3)\end{array}$ \\
\hline 1995 & 2.45 & 12149.5 & 0.79 & 1.60 & $\begin{array}{l}116.5 \\
(19.3)\end{array}$ & $\begin{array}{c}1061.0 \\
(518.7)\end{array}$ \\
\hline 1996 & 2.79 & 19393.9 & 0.90 & 1.60 & $\begin{array}{l}112.7 \\
(19.5)\end{array}$ & $\begin{array}{c}990.7 \\
(484.8)\end{array}$ \\
\hline 1997 & 3.04 & 24449.7 & 0.99 & 2.02 & $\begin{array}{l}110.1 \\
(20.1)\end{array}$ & $\begin{array}{c}934.6 \\
(455.1)\end{array}$ \\
\hline 1998 & 2.84 & 25082.1 & 0.92 & 1.60 & $\begin{array}{l}105.9 \\
(20.5)\end{array}$ & $\begin{array}{c}855.2 \\
(417.0)\end{array}$ \\
\hline 1999 & 3.31 & 48050.5 & 1.01 & 1.61 & $\begin{array}{l}105.7 \\
(21.2)\end{array}$ & $\begin{array}{c}872.4 \\
(420.2)\end{array}$ \\
\hline 2000 & 3.85 & 76697.1 & 1.09 & 1.63 & N/A & $\begin{array}{c}887.7 \\
(425.9)\end{array}$ \\
\hline 2001 & 4.17 & 105225.8 & 1.16 & 1.67 & N/A & $\begin{array}{c}895.0 \\
(428.3)\end{array}$ \\
\hline
\end{tabular}

Source: State Committee on Statistics, Russian Statistical Yearbook, Moscow State Committee on Statistics, Social and Economic Situation in Russia, Moscow $\mathrm{N} / \mathrm{A}=$ not available.

On top of investment cuts and due to budget deficits, only part of the allocated funds were actually made available to research institutions. And funding cuts were not equally shared by all Russian R\&D organisations. In 1996, for instance, the Russian Academy of Sciences received about 78\%, and the Russian Federation for Basic Research about 37\% of their budget allocations. Many other R\&D 
institutions received significantly less than the amount allocated. The Ministry of Science and Technology, e.g. received about $50 \%$ of its budget and The Russian Space Agency about 80\% (Gokhberg, 1998).

According to the National Council for Science and the Environment (NCSE, 1998), if the US government had reduced its $R \& D$ funding by the same rate, the US national R\&D system would be in deep crisis. But even then, the situation in the US probably would not have been as severe as it is now the case in Russia because the US has a large private sector R\&D system. In Russia, however, the share of direct industry funding is relatively small and the government keeps its dominant role in funding R\&D (Radosevic \& Auriol, 1999). As shown in Fig. 1, throughout the nineties the government provided most of Russia's GERD.

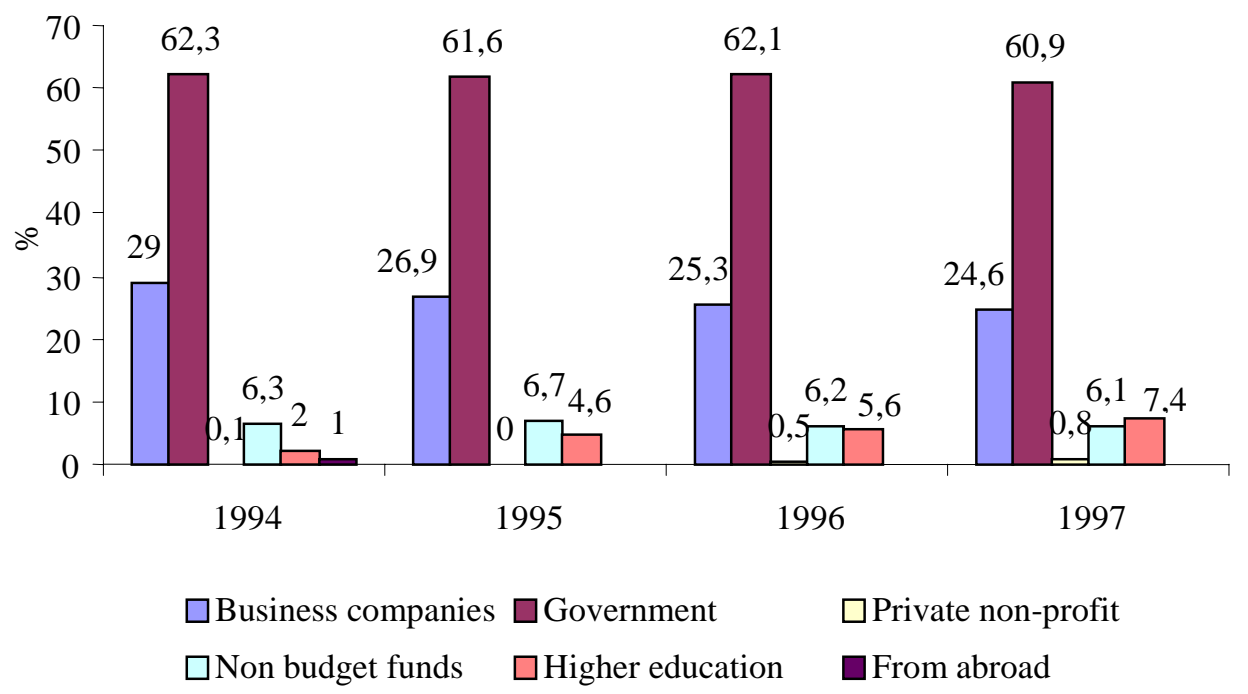

Source: Centre for Science Research and Statistics. Ministry of Science and Technological Policy of Russian Federation and Russian Academy of Sciences.

Fig. 1. Gross domestic expenditure on R\&D by source of funds in 1994-1997.

During the transitional period, a system of industry-oriented R\&D conducted mainly in independent institutes and mainly funded by the state was replaced by a system based on a three-fold structure, that is, a system with three distinctive institutional sectors - the government, the industry and the higher education sector (Radosevic \& Auriol, 1999). On the other hand, the restructuring of Russia's R\&D system also involved its reorientation toward civilian R\&D. The proportion of military/space R\&D has declined from more than $70 \%$ of GERD to about 


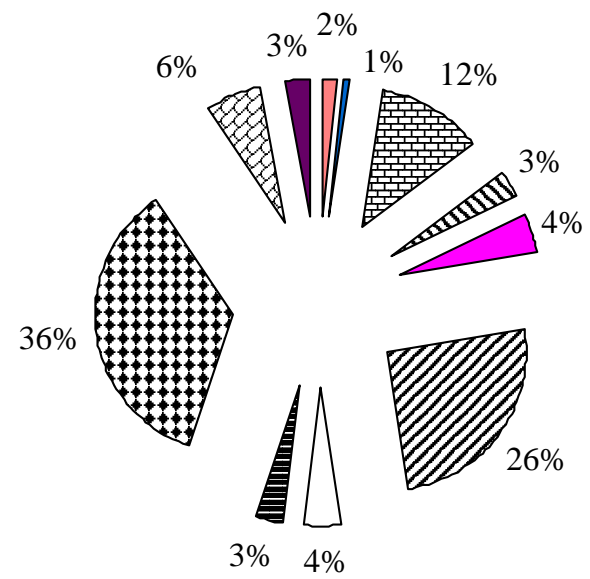

圈 Agriculture
国 Energy
国 Industrial development
⿴囗ther economic objectives
$\square$ Health
$\square$ Environment
$\square$ Social development
国 Basis science development
@ Earth and atmosphere
$\square$ Space
$\square$ Defense (military objective only)

Source: Centre for Science Research and Statistics. Ministry of Science and Technological Policy of Russian Federation and Russian Academy of Sciences.

Fig. 2. Gross domestic expenditure on R\&D by socio-economic objectives (1994).

30\%, during the 1989-1994 period (Gokhberg, 1998). Figure 2 indicates the structure of Russian GERD by socio-economic objectives, in 1994. Total R\&D funding for 1997 was roughly one-half civilian and one-half military (NCSE, 1998).

Under the impact of the transition to a market economy, R\&D institutions have made significant restructuring efforts in order to adapt to the new economic environment and particularly, to survive under severely unfavourable financial conditions. Considerable changes have taken place in all four major R\&D sectors - the Academy, higher education, industrial $R \& D$, and the enterprise sector (Ivanova, 2001; Gokhberg et al., 1994). The private non-profit sector, on the other hand, is still residual in the Russian R\&D system. Overall, the basic funding pattern has suffered only limited changes. In fact, as pointed out above, the state remains the main research funds provider.

The USSR Academy has been transformed into the Russian Academy of Sciences (RAS). The RAS has largely retained the commanding position of its USSR predecessor and maintained administrative control over the activities of its research institutes. To date, the Academy has not significantly changed the structure and bureaucratic organisation it had in the Soviet era. Using its considerable political influence, the Academy has managed to retain its budget financing better than other R\&D sectors. Government financing has largely been in the form of support to basic research. Applied R\&D continues to account for more than one-third of the Academy's activities. Academy institutes have maintained some participation in budget-financed goal-oriented S\&T programs. 
Higher education institutions are still modest players in the $R \& D$ game. Universities were traditionally primarily teaching institutions (Radosevic \& Auriol, 1999) though recently there is tendency in some disciplines to integrate institutes of higher education with research institutions (Ofer \& Polterovich, 2000). Economic difficulties have reduced the role of university $R \& D$ in general. In many universities, R\&D is no longer considered an economically "profitable" activity, thus becoming a marginal one. R\&D is no longer carried out at $40 \%$ of higher education institutions, and the 150 newly established private universities have little interest in R\&D. The universities' share in basic research increased (in both absolute and relative terms) because applied R\&D performed on contracts with industry decreased sharply, leaving them more dependent on budget funds for basic research. Universities, however, are having difficulties competing with Academy institutes in basic research and with industrial organisations in applied R\&D. Additionally, few development activities are carried out in universities. As a result, universities are struggling to play any relevant part in the overall R\&D effort.

Industrial R\&D has retained its share of GERD of over 75\%. In fact, Russian $R \& D$ has been carried out to a considerable extent in industry-oriented independent institutes though mainly funded by the government. Industrial R\&D institutes have retained strong links with business companies, usually in the framework of institutional structures such as associations, financial industrial groups, and large conglomerate firms that have partly replaced ministerial branches. As a result, these institutes were able to responded to the short-term requirements of the industry. But their share of long-term research has declined as companies have little interest in financing such activity, given the current financial situation. Deterioration of the financial position of the large industrial R\&D institutes, however, has forced them to increase their efforts on basic research financed by the government (especially in the case of the defence industry), thus competing directly with Academy institutes for support.

Direct R\&D investment from business companies also remains limited. Overall, the business sector still represents a relatively small proportion of $R \& D$. But development activities usually financed by the companies themselves have seen some increase. There was a modest increase in the companies' share of the total R\&D effort in the 1990s largely due to the need felt by some of them to keep their in-house R\&D units. On the other hand, foreign-owned R\&D-performing organisations and other international joint ventures involving $R \& D$ have increased throughout the nineties but their number is still limited (Dyker, 2001).

The dramatic fall in state $R \& D$ funding led to a similar decrease in $R \& D$ employment and in scientific degrees awarded. Total R\&D personnel fell by some 60\% in the 1989-2001 period, and the number of researchers and technicians 
fell by about $70 \%$ in the same period. Other sectors in the economy also suffered radical transformations but the most dramatic fall in numbers employed among all major branches of the economy was registered in R\&D (Tikhomirov, 2000: 216). Table 2 also shows that over the period 1992-1999, the number of scientific degrees awarded decreased by about $18 \%$.

Allowing for some differences in statistics from different sources, the Russian R\&D workforce might not have reached its appropriate size yet, given the evolving Russian R\&D structure and political priorities. Some experts argue that the sharp decrease in the number of scientific degrees awarded and in R\&D personnel may not be entirely dramatic because it is generally conceded that the Russian R\&D institutions have an over manning problem when comparing to the scientific and engineering workforce in most other countries. For example, Japan, whose R\&D system is more labour-intensive, employed some 450,000 research scientists and engineers (RSE) for an economy that seemed equivalent, in real terms, to Russia's. The USA employed in the late 1980s about one million RSE full-time equivalent (FTE) for an economy that, in real terms, seemed three times bigger than Russia's. These data give some benchmarks for the size that seems reasonable for Russia (NCSE, 1998). In terms of R\&D personnel per thousand labour force, Russian figures were about 16.6 in the mid-1990s. In other words, Russian figures were still the highest in the world, higher than those of Japan (14.2), France (12.5) and Germany (11.9) (Radosevic \& Auriol, 1999: 356). These authors argue that the still high numbers of R\&D personnel in Russia reveal the inability of the economy to absorb the surpluses of employment in the R\&D system rather than a sign of robustness of R\&D in the Russian economy.

\section{External and internal "brain drains"}

The downsizing process in the scale seen in Russia in the last 12 years inevitably brought personal hardship to the unemployed scientists and engineers and it was a serious drawback to the Russian R\&D system. A major problem to this system is the "brain drain", both external and internal. The first and greatest wave of expatriates, in 1992 and 1993, included some of Russia's scientific and engineering elite. However, some of them may return. In fact, the number of scientists and young researchers who have been going out of the country with a labour contract in hand is substantially higher than the numbers of those who have taken up permanent residence abroad (Ushkalov \& Malakha, 2001). In addition, many Russian students studying abroad will probably return, although not until after they are 28 years old, in order to avoid the military draft. On the other hand, the "brain drain" has not affected all sectors in the same way. For instance, the migration of nuclear weapons scientists, a potentially dangerous situation, is 
probably minimal due to laws restricting the travelling of such scientists and the result of international programs encouraging them to stay.

Official statistics lack reliable data on the size and composition of the Russia's scientific diaspora but some estimates referred to by Ushkalov \& Malakha (2001) put the overall figures above 100,000 individuals. And a survey of migration behaviour of college students and science workers referred to by the same authors show that the level of intentions to migrate among scientists is rather high (almost one in two). Wide wage differentials create strong incentives for the most qualified scientists to search for jobs in another country. But the declining level of prestige of science in society, the lack of opportunities to realise themselves as scientists, and the uncertain career prospects were also identified as decisive factors accounting for the outflow of scientists to other countries (Ushkalov \& Malakha, 2001: 86).

However, despite the significant migration of scientists to other countries, figures for the external "brain drain" can be considered as relatively small when compared to figures for the internal "brain drain". From the approximately half a million to 600,000 scientists and engineers who left their professions from 1990 to 1995 , possibly more than half of them have found new careers in Russia, many of them in the emerging market economy where salaries are much higher. Most of the staff reductions were voluntary departures. The opportunities and rewards in business have made the sector increasingly attractive to qualified and enterprising people. Seventy-one percent of those leaving R\&D employment rank higher salaries as a prime reason for their decision (Dynkin, 2000). Highly qualified researchers can easily find employment in the rapidly growing business sector, and many top-level managers of banks, industrial groups, joint ventures, and newly privatised companies have doctoral degrees in scientific fields. These well-educated and motivated individuals have certainly contributed significantly to the evolving market economy. Banking, for instance, has recently become a prestigious and desirable career, and former physicists and mathematicians are among its most successful practitioners. This redistribution of talent in favour of new market segments is probably positive for the national economy as a whole but a loss to the R\&D system.

Less-qualified staff members, experiencing difficulties in employment, are returning to the relatively low-salaried positions in the government-supported R\&D sector (Dynkin, 2000). To survive, many researchers take parttime employment outside their institutes. According to some estimates, $57 \%$ of all researchers have contracts with private firms and $80 \%$ of these researchers are also employed by the Academy (Gokhberg, 1998). Some former scientists and technicians who became jobless in consequence of the downsizing process have developed new entrepreneurial ventures (Bruton \& Rubanik, 1997). These 
entrepreneurial individuals established their own small companies to raise their incomes and to be free of bureaucratic supervision. Small companies were often created as spin-offs from large research institutes. In many cases, small business units were used as instruments to avoid taxes and overhead expenses. Some of them leased property and equipment from the main institutes, and others used the facilities unofficially. Many individuals involved in these small companies remain as employees of the large institute, working only part-time in the new small venture (Gokhberg, 1998).

The decline in the Russian R\&D potential is not just prompted by the massive outflow of scientists. The picture gets bleaker when it is observed that the most talented, those whose competencies are in big demand in the international market, and particularly the younger are more likely to go abroad or to make a career shift toward the private sector. Because many young scientists and engineers have not retained their jobs in the $R \& D$ institutions, the average age of the remaining $R \& D$ personnel has increased significantly and is now about 55 years old. And leading research centres are the ones facing the greatest threat, according to Ushkalov \& Malakha (2001). This will certainly have negative implications for the future of Russian R\&D.

\section{Threats and challenges to the Russian innovation system}

A characteristic of the current situation is Russia is the weakness of business innovation. In centrally planned economies, little R\&D was conducted in-house. Independent institutes that directed their research to the needs of industry performed most R\&D activities. Although formally independent, these institutes were essentially financed by the government (Radosevic \& Auriol, 1999). These industrial branch institutes have suffered most with the abolition, in most cases, of their hierarchical superiors and patrons under the old system, the industrial ministries. Nowadays, these institutes keep their industry-orientation and are partly financed by the private sector, acting as independent contract researchers or consultants. At the firm level, R\&D activity has fallen even more, due to the lack of incentives to introduce innovations in industrial firms, and other general barriers to innovation. In addition to these barriers, the Russian R\&D system is characterised by a separation of $\mathrm{R} \& \mathrm{D}$, technology and production, weak institutional linkage, and virtually no linkage between marketing, production and procurement. Perhaps more than the continuous decrease in R\&D funding and the loss of $R \& D$ personnel, these might be the most serious factors in the long-term health of Russian $R \& D$. This section explores briefly the major threats and challenges to the Russian innovation system. 
Apart from the general challenges of managing technical innovation, Russian firms have to cope with additional obstacles. Some problems and restrictions for the innovative capacity arise from macroeconomic and political conditions. The most important barrier to catch up with Western competitors by technical innovation is the availability and cost of capital. Underdeveloped financial systems, questionable profit prospects and limited capital all have been negative investment factors in Russia. Besides, the excessive taxation of business activities, which can be as high as $50 \%$, do not encourage entrepreneurial initiatives to manufacture, and especially to innovate and produce hi-tech products (Dynkin, 2000).

The policymakers in Russia have attempted to transform the R\&D sector mainly through new legislation and tax incentives. These attempts, however, were being made within the old centralised system of S\&T management with all its inter-sectorial barriers and centralised financing. Most government R\&D funds are still distributed through old industrial ministries or departments that control specific programmes. The share of government R\&D funds distributed on a competitive basis remains small. There is a long way to go to create an efficient and internationally competitive S\&T system (Gokhberg et al., 1994).

But according to many experts (Varshavski, 1998), the period of transition from the well financed though inefficient Soviet R\&D system to a significantly changed Russian system of innovation will probably continue for another 10 to 15 years. That is why it is so important for Russia to pay a special attention to supportive policies of the national innovation system while overcoming economic crisis and implementing technological change.

In spite of the considerable decrease in government funding, the Russian government still has more control over the nation's science and technology policy than do governments in other industrialised countries. The ongoing governmental R\&D funding cuts give added importance to Russia's technology development programmes conducted in support of its market reform policies. Several budgetary and non-budgetary foundations allocate support through competitive bids. Some of these foundations are listed in Table 3. They were established by the government to strengthen project selectivity, increase $R \& D$ investment, stimulate the initiative by researchers and involve them in industry-supported applied R\&D. Nonbudgetary funds draw support from industrial firms through a procedure established by the state. These programmes are considered a transitional stage in the process of moving from government to private funding of $R \& D$ (Gokhberg, 1998). If such programs are successful, the still small non-governmental R\&D sector may contribute more to the nation's research and technology development activities than it has in the past.

Among the foundations listed in Table, the activities of the Russian Foundation for Technology Development (RFTD) and the Russian Foundation 
Table 3. Foundations promoting $R \& D$ in Russia.

\begin{tabular}{ll}
\hline \hline \multicolumn{1}{c}{ Budgetary Foundations } & \multicolumn{1}{c}{ Non-Budgetary Foundations } \\
\hline Russian Foundation for Basic Research & Russian Foundation for Technology Development \\
Russian Foundation for Research in Humanities & Russian Foundation for Conversion \\
Russian Foundation for the Promotion of S\&T & \\
in Small Firms & \\
Russian Foundation for Support to & \\
$\quad$ Young Scientists & \\
Federal Foundation for Industrial Innovations & \\
\hline \hline
\end{tabular}

Source: Gokhberg et al. (1994).

for Promotion of S\&T in Small Firms (FPSF) are directly associated with applied R\&D. The RFTD, established in May 1992, is a centralised non-budget foundation, which, along with 71 sectorial non-budget programmes attached to the different ministries or industrial associations, is financed by the contribution of $1.5 \%$ of sales revenue of industrial firms. These contributions are divided as follows: three-quarters of the amount collected are to support sectorial non-budget programmes and the remaining one quarter goes to the RFTD. Initially, it was assumed that these funds would be used to maintain existing industrial $R \& D$ institutions. Over time, however, the emphasis has shifted to projects that introduce innovations. In 1994, the FPSF was created to assist small innovative enterprises, granting preferential credit to small innovative firms that are entering the market with high-tech products (Dezhina \& Graham, 2001). And in the year 2000, the first venture capital fund was set up in Russia.

It is worth pointing out that the volume of imports and exports of technology items remains very low for an economy the size of Russia's, as illustrated in Table 4. Among the OECD countries only the small economies of Finland and Norway have comparable figures in these trade items. This comparison suggests that Russia is still not completely integrated into the international market for intangible S\&T transactions and there is a considerable unexplored business potential for international firms. A decrease in technology imports would further isolate Russia from the countries with the most advanced world innovations and continue to aggravate technological backwardness of some of its industrial sectors. The painful beginning of a new commercial culture of high technology, especially for small companies, is only now starting to emerge (Dezhina \& Graham, 2001).

Business sector R\&D collaboration between Russia and the Western economies can play an important role in the renewal of Russian economy. The number of 
Table 4. Selected Output Russian Research and Development indicators (1993-2000).

\begin{tabular}{|c|c|c|c|c|}
\hline \multirow[b]{2}{*}{ Years } & \multicolumn{2}{|c|}{ Trade of Technology } & \multicolumn{2}{|c|}{ Patent Applications Filed } \\
\hline & $\begin{array}{c}\text { Value of Export Contracts, } \\
\text { Million Rubles }\end{array}$ & $\begin{array}{c}\text { Value of Import Contracts, } \\
\text { Million Rubles }\end{array}$ & Residents & Non-Residents \\
\hline 1993 & & & 28478 & 3738 \\
\hline 1994 & & & 19482 & 3599 \\
\hline 1995 & & & 17551 & 4651 \\
\hline 1996 & & & 18014 & 5197 \\
\hline 1997 & & & 15106 & 4886 \\
\hline 1998 & 728.4 & 870.1 & 16454 & 4908 \\
\hline 1999 & 3256.0 & 21769.4 & 19900 & 4759 \\
\hline 2000 & 1192.9 & 11663.5 & 23377 & 5311 \\
\hline
\end{tabular}

Source: State Committee on Statistics, Russian Statistical Yearbook, Moscow.

wholly or partly foreign-owned R\&D-performing companies has risen during the nineties, though the degree of internationalisation of $R \& D$ is considerably lower than the one found in other sectors, and the level of formal international R\&D collaboration has been lower for Russian than for other Eastern European countries (Dyker, 2001). According to this author, Western investors are generally unhappy about levels of tax and, above all, about the speed with which the effective tax burden can change rendering investment planning virtually impossible. On the other hand, "company law, intellectual property rights, property law, bankruptcy law and legal recourse also present a whole range of difficulties" (Dyker, 2001: 863), working in practice as restrictions on foreign ownership and foreign control of firms and joint ventures, and as a major obstacle to the transfer of know-how and technology.

Russian companies frequently have little experience in dealing with information and customer networks. As a rule, all strategies of product innovation require newly established or intensified contact to customers. It probably is the most important management task for Russian companies to understand the markets and to build up market knowledge through the creation of networks (Witt, 1998). Difficulties also arise for the creation and the restructuring of supplier networks. On the one hand, the interaction with suppliers becomes more demanding for Russian companies because of the break down of co-operation among regions and republics of the former Soviet Union. On the other hand, suppliers, just like customers, are an important source of technical innovation. Russian companies have little experience in choosing suitable suppliers, in drawing technological know-how from suppliers, and in co-operating with them. It is another important 
management task for Russian companies to catch up with Western competitors in terms of exploiting supplier relations for technical innovation purposes.

Another weakness is the lack of consulting services regarding innovation management and finance. There is a need for this kind of support in addition to the provision of technical know-how. This function could probably be taken over by existing consulting organisations and technology centres. Since the early 1990s, 65 technoparks and business incubators were created in 32 Russian regions. At the present time, most of them provide only a limited range of services (like renting, consulting business plan, etc.). These institutions are having an increasing role in Western economies and their aim is to promote and ease the linkages among the economic agents, thus facilitating the production and diffusion of technological innovations (Furman et al., 2002). Finally, the management of technical innovation in Russian firms also implies organisational changes like restructuring the workflow, new organisational structures, and innovative personnel management. In most companies, personnel management is still reduced to the traditional tasks of registration of those being hired and leaving and the preparation of statistical reports (Clarke \& Kabalina, 2000). Human resource management, as it is understood in the West is virtually non-existent.

Environmental regulations, nearly unknown in socialist times, are slowly being established, affecting process innovations. Frequent changes in the regulatory framework concerning new technology raises uncertainty about the consequences of technical innovations. In general, inadequate legal frameworks and frequent changes in regulations raise transaction and start-up costs, thus making the introduction of new products to the Russian market particularly difficult (Kuznetsov et al., 2000). In contrast with most Western countries where legislation is generally intended to attract new businesses and promote new ventures, in Russia the whole system of state regulation is like an endless ladder where every step is an obstacle provoking the small entrepreneur to abandon the business (Barkhatova, 2000). Above all, general political instability must be recognised as a serious problem for long-planning technical innovation and corporate restructuring and a deterrent to foreign investment (Dyker, 2001).

Additionally, a tradition of relying on business informal arrangements and networks, a deficient tax system, and a deep mistrust between participants in business transactions (Kuznetsov et al., 2000) lead many entrepreneurs to work "either to a large extent or wholly illegally" (Barkhatova, 2000: 657-658). Under the pressure of cash shortage, both R\&D institutes and business firms have turned to "moonlighting" as a means of survival. Where this "moonlighting" has involved the provision of R\&D services to market-oriented clients, the structural implications have been positive. In many cases, however, the "moonlighting" has diverted R\&D organisations and workers from their core business. The preferred 
institutional money making scheme is to rent out part of their building to a commercial company. And institute employees often make ends meet by doing ancillary work which may require specialist knowledge and access to institute equipment, but which has no R\&D content as such. Nevertheless, this seems to show that the so-called non-commercial culture of the old system of central planning (Dyker, 2001) may no longer be as deep-seated as it is often assumed.

\section{From Decline to Recovery of Russian Economy and the Expected Role of R\&D: Policy Implications}

The speed up of technical progress has become one of the main features of economic reform undertaken in different countries in the last decades, both East and West. The direction of the changes taking place in their economic systems is country specific, but a common theme appears to emerge - the relatively weak innovative capacity of the national economy. This is proven to be difficult in a market economy, and it will be even more so in Russia's current transformation process.

In Russia, the prerequisites for implementing a technological change and overcoming economic crisis are gradually forming. As point out above, Russia inherited from the Soviet Union one of the biggest R\&D complex the world as ever seen. And despite the problems the Russian economy currently faces, the actual $R \& D$ potential is still able to contribute significantly to national economic growth in the long term as it has done in the US and other industrialised countries, and in the newly industrialised countries of Asia (e.g. Singapore, South Korea, and Taiwan). To encourage such a development requires moving from widespread support of the numerous $R \& D$ institutions inherited from the Soviet era to a system more consistent with a market economy. As time passes, federal agencies will become less able to carry out a top-to-bottom transformation of the S\&T activity. Many R\&D institutions are being privatised, so that highly qualified research teams are no longer under government control. As pointed out above, the share of the government budget in the nation's expenditure on R\&D is declining, and the need for a new S\&T policy is becoming more widely recognised. Direct management by the state should be replaced by indirect measures, and state support should be limited to the most promising activities (Gokhberg et al., 1994).

On the other hand, there is evidence that business firms are slowly adjusting to a market economy, taking the first steps toward internationalising their activities and providing greater support for $\mathrm{R} \& \mathrm{D}$. Besides, despite the sharp reduction in R\&D spending and personnel, Russia keeps a high share of R\&D employment in the total labour force and a high share of $R \& D$ carried out in the business 
sector (Radosevic \& Auriol, 1999). In other words, the Russian R\&D potential despite the continuing degradation in the last decade is still far from negligible.

The efforts to improve the innovation capacity in Russia are pursued through various measures and approaches in which the central government still has an important role to play by committing itself to expanding traditional central innovation policies, and "pumping" innovations into the economy. But at the same time, it is searching for new ways of stimulating new ventures and promoting high-technology start-ups (Bruton \& Rubanik, 1997).

The promotion of innovation activities and economic growth in Russia requires a more comprehensive stabilisation policy than the one currently in force. A switch to a reliable and growth-oriented macroeconomic policy is a necessary but not sufficient condition for promoting innovation. In its efforts to promote R\&D the state should not be seen as a substitute for the market but rather as helping firms to adjust to market competition. For instance, state purchase of new products is most important at the earliest phases of their introduction to bring down unit costs. This policy is actively used in many industrialised countries. The goal of state programmes is to support the initial phases in the life cycle of new products to create favourable conditions for the restructuring of production facilities. Private funding should be involved in financing innovations, but Russia should also learn from other countries where joint public-private funding and risk sharing by the state and private organisations has proved to be an effective format. Government financial support of high-risk projects may also promote innovation. Public policy is needed to improve the infrastructure and financial conditions so that small enterprises can focus on developing innovation. In spite of the role of large firms, companies owned by individuals risking their own capital remain an important force in a market economy. Small firms have been the source of many radical innovations (Gokhberg et al., 1994).

Economic and S\&T measures are required for bridging the gap with the more advanced economies. On the one hand, the right conditions for business innovation to flourish have to be created, in particular in small and medium sized businesses. That means a stable macroeconomic environment with properly functioning financial, labour and goods markets, and a regulatory set-up that promotes competition and innovation. It includes favourable tax regulation and protecting intellectual property rights. At the same time, by improving the general business environment Russia would be able create new jobs for agencies engaged in R\&D activities. On the other hand, a selective scientific and technological policy has to be worked out and implemented, comprising an active state support for basic and applied research, and innovations. Investments should be directed to the creation and rapid diffusion of technologies that provide mastery of the contemporary technological structure and create a scientific and technological 
basis for its improvement. For that purpose, it is necessary to use the potential for conversion of the defence science and industry. The key role in solving these tasks belongs to the system of special federal scientific, technical and investment programmes (Yakovets, 1994). Measures to ease access to venture capital and to enhance the commercialisation of public-funded research are major elements in these initiatives.

Radical changes in structural policy are also required. In the past, priority was given to the defence sector and to heavy industries. However, in recent years the share of machine-building, light and food industries in the manufacturing sector has decreased (Tikhomirov, 2000). The consumer sector and high-tech production of competitive manufacturing export goods are still underdeveloped. Modern means of production for these sectors are strongly needed. At the same time, subsidies to obsolete, loss-bringing companies should be eliminated, and antimonopolistic policies put in place, especially in more sensitive sectors. The current process of privatisation and development of market competition can make a contribution towards those goals.

However, technological change is not possible without a radical change in the educational and training system in order to accommodate continuous education and a large-scale training programme of the human resources. In connection with radical changes in the technological and economic conditions and in the transition to a market economy, lack of skills and professional obsolescence of workers, engineers, and managers has increased greatly and does not allow Russia to master, produce, sell (in both domestic and foreign markets) and effectively use high-technology products, ensuring their competitiveness. It seems universally accepted that the educational system, supplemented by training and skills upgrading of the human resources, has a significant impact on industrial performance. In Russia, however, a sharp decline in the financing of higher education by the federal budget, both in absolute and relative terms, is not helping the required university renewal. Many features of the new economic system are not clarified yet, and "improving the economic situation of the universities would involve completing a number of reforms that have not been pursued to date with sufficient vigour and consistency" (Hare \& Lugachev, 1999). In business related fields in particular, inherited traditions in economics teaching and the lack of qualified teachers appear to remain enormous obstacles to market-economy business education (Ofer \& Polterovich, 2000).

Further improvements are required in the innovation system itself. As mentioned earlier, the traditional (linear) model of technological development is increasingly inadequate. The process of innovation is becoming more complex, occurring at many stages and through many agents. Innovation no longer depends only on how firms, universities, research institutes and regulators perform, but on 
how they work together. This implies regulatory improvements that stimulate innovation and strengthens the link between scientific research and the innovation process. Co-operation between the public and private sectors is becoming more important as industrial patents increasingly rely on basic, publicly supported research performed at academic, governmental and other public institution levels (Yakovets, 1994).

Russia is also a huge country with considerable regional differences in terms of economic specialisation and development stage. Increasingly, innovation becomes a collective and interactive process, which should be supported by systems of innovation at national as well as regional level, because when it comes to innovation, 'space' also matters (Koschatzky, 1998). A policy oriented towards the effective use of national innovation resources might have a positive impact on regional development. With regard to regional and sector specificity, public regional innovation promotion has, therefore, a triple task (Koschatzky \& Sternberg, 2000):

- Activation and careful complementation of regional resources for the development and application of new technologies (regional innovation conditions),

- Co-ordination and inter-linking of these resources in regional innovation networks, bringing in all the relevant actors in industry, science and policy,

- Integration of these regional networks into national and international clusters of technology development and production, by the creation of active interfaces and the promotion of supra-regional co-operation.

Depending on the specific conditions of the region, a need for targeted initiatives at a regional level arises, directed towards priority problem areas and bringing together regional players by actions that are project-based or measure-based. These initiatives could be translated by the provision of resources (personnel, finance, and equipment) and by policy legitimisation. They have been mainly publicly initiated and carried out by regional key figures (promoters) in politics, industry and science, and sometimes supported by external specialist advice, and regional co-ordinating bodies and committees. In this context, a total of 59 of the 89 regional authorities of the Russian Federation participate in regional S\&T programmes that include interregional economic associations, such as the Association for Economic Interaction of Regions of the Central Black Earth Area Chernozemye, the Association Siberian Treaty, and the Association for Economic Interaction of Regions and Republics of the Urals Area. The Krasnodar, Irkutsk, Saratov, Kemerovo, Tomsk, and Tula regions are among the most active participants in regional S\&T programmes. In spite of the fact that financing of regional programmes is an insignificant part of the federal budget, these 
programmes are a radically new form of co-operation between the federal government and the regional governments. The programme takes into account local needs or preferences. Shared financing and the need of funds from local budgets, industrial enterprises, and other sources increases the responsibilities of local administrators and R\&D participants in the projects. Careful assessment of these programmes is obviously required and if proved successful, extended to other regions.

Nevertheless, regional development can also be promoted by the central government. A central regional policy aims to reduce socio-economic disparities with reference to the national average. Infrastructural measures (involving transport, telecommunication and energy systems), regionally-differentiated investment grants and tax reductions can stimulate intra-regional or external economic potentials and temporarily increase mobility of production factors oriented towards the region. In the long term, these measures can contribute to stabilisation of the national system.

Co-operation with developed countries is also very important. Learning from reform efforts of OECD countries and others possessing the type of business climate where innovation can flourish is very useful. Russian could learn from countries like France, Mexico, Japan, Korea, Finland and Austria, which have taken comprehensive policy initiatives to strengthen their innovation systems. One reason is that innovation has to be shared for it to thrive. Equally important, governments now have a new and responsible role, which is to build the coherent policies needed for innovation to flourish and the knowledge-based economy to grow and prosper.

\section{Conclusions}

To strength their position in international competition, national economies have to increase their efforts to produce new technology and to adapt and diffuse innovations. Most advanced economies have perceived this changing environment and devoted a greater attention to science and technology, by creating a variety of instruments to support research activities and technological development. On the other hand, national economies are becoming more closely integrated into the global economy, where the mobility of goods, services, and capital has increased to a point unforeseen only two decades ago. Moreover, there is an increasing appreciation that in the long term, the ability to master technology and to manage and generate technological change is decisive in determining an economy's competitive strength and capacity to grow.

It has been argued that innovations can play an important strategic role in achieving competitive advantage and that the innovation processes have become 
more interdependent. Views about the innovation process have changed considerably in the past few years. There has been a shift from a firm-centred approach towards an interdependent and systemic perspective. Increasingly, innovation is seen as a collective and interactive process between firms, knowledge suppliers and other organisations, that can be supported by systems of innovation at national, regional and sectorial levels.

Mastering technological innovation is not a simple task. National success in innovative capacity requires the combination of different factors, including high quality research, supportive policies, and adequate managerial skills. These factors are unevenly distributed across different national systems of innovation, resulting in substantial differences in the quality, nature and trajectory of innovations produced. Since innovation is becoming a key factor in the competition between countries, those where barriers to innovation are higher will lose ground relative to their competitors.

According to the data and the analysis presented in this paper two major changes occurred in the Russian R\&D system. The first relates to the significant downsizing of the inputs dedicated to research activities, namely the severe cuts in funding and in the number of personnel engaged in these activities. The second concerns an institutional change that is represented in the agents that constitute the pillars of the national system of innovation.

An important aspect to consider is that despite the strong decrease in the inputs of the innovation process, Russia still maintains a strong position when compared to OECD-25 countries (see also Radosevic \& Auriol, 1999). This position gives Russia a key advantage in the international arena because it means that Russia is endowed with strong technological capabilities that are essential not only to the production but also to the absorption of new knowledge, which means potentially higher diffusion rates of new technologies (Faria, forthcoming). Indeed, being first to adopt technological innovations means approaching faster the technological frontier, and consequently increasing productivity. Despite this potential advantage, the innovative capability of Russia should also be translated in its ability to produce and commercialise a stream of technological innovations over the long term. In other words, a country's innovative capacity depends essentially upon its infrastructures (e.g. resources dedicated to innovativeness), the environment in which economic agents operate (e.g. economic and social policies), and the linkages between these two (see, for example, Furman et al., 2002).

As such, some policy implications can be drawn, which we believe to be relevant to Russia's future as well as to other transitional economies. Firstly, innovation policies should promote the relationship between producers and users of innovation, that is, to strength the linkages among the triad government- 
industry-university, as has been done throughout OECD countries. Secondly, an effective Intellectual Propriety Rights system should be implemented in order to promote domestic R\&D and international investment. Thirdly, openness to international trade should be guaranteed in order to foster the flow of hightechnology products and consequently lead to the development of industries with increasing value-added. Finally, policies promoting social cohesion should be implemented simultaneously; otherwise the expected positive impact of the innovation process runs the risk of being lost, as the majority of society has not the capability of absorbing it (Lundvall, 1999).

In summary, it was argued that the R\&D potential of the Russian society can play a decisive role in overcoming the current economic crisis and implementing a technological change if some considerable barriers are overthrown. It was also pointed out that the Russian innovation system needs to be improved and important policy changes have to be made in the economic, financial, legal, and S\&T spheres. R\&D and technology policies have to be integrated in order to create the effective innovation support structures at both the national and regional levels. Following these paths, Russia may be able to renew herself and regain her place among the more advanced economies.

\section{Acknowledgements}

The authors wish to express gratitude to the TEMPUS TACIS Programme (Project M-JEP-10723-1999), which provided financial support that made this research possible. They also would like to thank two anonymous referees for their valuable and helpful contributions to this paper.

\section{References}

Abramovitz, M. (1991) Thinking about Growth and Other Essay on Economic Growth and Welfare. Cambridge: Cambridge University Press

Archibugi, D. \& Pianta, M. (1993) Patterns of technological specialisation and growth of innovative activities in advanced countries. In European Competitiveness, ed. K.S. Hughes, pp. 105-132. Cambridge: Cambridge University Press

Asheim, B.T. (1996) Industrial districts as learning regions: A condition for prosperity? European Planning Studies, 4(4), 379-400

Audretsch, D. (1993) Industrial policy and international competitiveness: The case of Eastern Europe. In European Competitiveness, ed. K.S. Hughes, pp. 259-290. Cambridge University Press

Autio, E. (1998) Evaluation of RTD in regional system of innovation. European Planning Studies, 6(2), 131-140 
Barkhatova, N. (2000) Russian small business, authorities and the state. Europe-Asia Studies, 52(4), 657-676

Bruton, G. \& Rubanik, Y. (1997) High technology entrepreneurship in transitional economies: The Russian experience. The Journal of High Technology Management Research, 8(2), 213-223

Clarke, S. \& Kabalina, V. (2000) The new private sector in the Russian labour market. Europe-Asia Studies, 52(1), 7-32

Cooke, P., Boekholt, P. \& Tödtling, F. (1998) Regional Innovation Systems: Designing for the Future. Final Report to the European Commission. Brussels: Commission for the European Communities

Dezhina, I. \& Graham, L. (2001) Russia taking first steps toward commercial culture for technology. Research-Technology Management, 44(2), 6-7

Dosi, G. (1988) The nature of the innovative process. In Technical Change and Economic Theory, ed. G. Dosi, C. Freeman, R. Nelson, G. Silverberg \& I. Soete, pp. 221-238. London: Frances Pinter

Dosi, G., Pavitt, K. \& Soete, L. (1990) The Economics of Technical Change and International Trade. London: Harvester

Dyker, D.A. (2000) The structural origins of the Russian economic crisis. PostCommunist Economies, 12(1), 5-24

(2001) Technology exchange and the foreign business sector in Russia. Research Policy, 30, 851-868

Dynkin, A. (2000) Outlines of Innovation in World Economy: Forecast for 2000-2015. Moscow: Nauka [in Russian]

Edquist, C. (1997) Systems of Innovation Technologies, Institutions and Organizations. London: Pinter

Fagerberg, J. (1987) A technology gap approach to why growth rates differ. Research Policy, 16, 87-99

Faria, A. (forthcoming) A count data model of technology adoption. Journal of Technology Transfer

Freeman, C. (1987) Technology Policy and Economic Performance: Lessons from Japan. London: Frances Printer

Furman, J., Porter, M. \& Stern, S. (2002) The determinants of national innovative capacity, Research Policy, 31, 899-933

Gaponenko, N. (1997) Innovacii i Innovacionnaia politika na etape perekhoda k novomu tekhnologicheskomu poriadku. Voprosy Economiki, 9, 84-97

Gittelman, M. \& Wolff, E.N. (1995) R\&D activity and cross-country growth comparisons. Cambridge Journal of Economics, 19, 189-207

Gokhberg, L. (1998) Nauchni potencial Rossii v zerkale statistiki. Voprosi Statistiki, 11, $18-31$

Gokhberg, L., Peck, M. \& Gacs, J. (1994) Russian Applied Research and Development: Its Problems and its Promise. Moscow: Centre for Science Research and Statistics

Hare, P. \& Lugachev, M. (1999) Higher education in transition to a market economy: Two case studies. Europe-Asia Studies, 51(1), 101-122 
Hodgson, G. (1988) Economics and Institution Manifesto for a Modern Institutional Economics. Cambridge: Polity Press

Ivanova, N. (2001) Forming and Evolution the National Innovation System. Moscow: INION [in Russian]

Kaufmann, A. \& Tödtling, F. (2000) System of innovation in traditional industrial regions. Regional Studies, 34(1), 29-40

Kay, N.M. (1988) The R\&D function: Corporate strategy and structure. In Technical Change and Economic Theory, ed. G. Dosi, C. Freeman, R. Nelson, G. Silverberg \& L. Soete, pp. 282-294. London: Pinter

Korres, G. (1996) Technical Change and Economic Growth: An Empirical Analysis of the EC. Aldershot: Avebury

Koschatzky, K. (1998) Firm innovation and region: The role of space in innovation processes. International Journal of Innovation Management, 2(4), 383-408

Koschatzky, K. \& Sternberg, R. (2000) R\&D cooperation in innovation system: Some lessons from the European regional innovation survey. European Planning Studies, 8(4), 487-501

Kuznetsov, A., McDonald, F. \& Kuznetsova, O. (2000) Entrepreneurial qualities: A case from Russia. Journal of Small Business Management, 38(1), 101-107

Lundvall, B.-A. (1992) National Innovation System: Towards a Theory of Innovation and Interactive Learning. London: Pinter Publishers

Lundvall, B.-A. (1998) Why study national systems and national styles of innovations? Technology Analysis and Strategic Management, 10(4), 407-421

Lundvall, B.-A. (1999) National business system and national innovation system. International Studies of Management and Organization, 29(2), 60-77

Mowery, D.C. \& Oxley, J.E. (1995) Inward technology transfer and competitiveness: The role of national innovation system. Cambridge Journal of Economics, 19, 67-93

NCSE (1998) Research and Development in Russia: An Important Factor for the Future. Congressional research service report. Washington: National Council for Science and the Environment

Nelson, R. (1993) National Innovation Systems: A Comparative Analysis. New York: Oxford University Press

Nelson, R. \& Winter, S. (1977) In search of a useful theory of innovation. Research Policy, 6, 36-76

Niosi, J., Saviotty, P. \& Crow, M. (1993) National systems of innovation: In search of a workable concept. Technology in Society, 15, 207-227

Ofer, G. \& Polterovich (2000) Modern economics education in TEs: Technology transfer to Russia. Comparative Economic Studies, XLII(2), 5-35

Porter, M. (1990) The Competitive Advantage of Nations. New York: The Free Press

Pratt, A. (1997) The emerging shape and form of innovation networks and institutions. In Innovation, Networks and Learning Regions, ed. S. James, pp. 124-136. London: Kingsley Publishers 
Radosevic, S. \& Auriol, L. (1999) Patterns of restructuring in research, development and innovation activities in central and eastern European countries: An analysis based on S\&T indicators. Research Policy, 28, 351-376

RIE (1999) Expertnoe zakluchenie Instituta economiki RAN na proekt federalnogo budjeta na 2000 god. Biznes $i$ Banki, 39, 11

Saxenian, A. (1994) Regional Advantage: Culture and Competition in Silicon Valley and Route 128. Cambridge, Ma: Harvard University Press

Schumpeter, J.A. (1934) The Theory of Economic Development. Cambridge, Ma: Harvard University Press

Sternberg, R. (2000) Innovation networks and regional development. European Planning Studies, 8(4), 389-401

Tikhomirov, V. (2000) The second collapse of the Soviet economy: Myths and realities of the Russian reform. Europe-Asia Studies, 52(2), 207-236

Tödtling, F. \& Kaufmann, A. (1999) Innovation system in regions of Europe: A comparative perspective. European Planning Studies, 7(6), 699-717

UN (1994) Technological Dynamism in Industrial Districts: An Alternative Approach to Industrialization in Developing Countries? Genève: United Nations Conference on Trade and Development

Ushkalov, I.G. \& Malakha, I.A. (2001) The "brain drain" as a global phenomenon and its characteristics in Russia. Russian Social Science Review, 42(5), 79-95

Varshavski, A. (1998) Social'no-ekonomicheskie problemi nauki: Dolgosrochnie aspekti razvitia. Voprosi Ekonomiki, 12, 68-72

Verspagen, B. (1994) Technology and growth: The complex dynamics of convergence and divergence. In The Economics of Growth and Technical Change: Technologies, Nations, Agents, ed. E. Elgar. Aldershot: Ashgate Publishing Limited

Witt, P. (1998) Strategies of technical innovation in Eastern European firms. Management International Review, 38(2), 161-182

Yakovets, Y.V. (1994) Scientific and technical cycles: Analysis and forecasting of technological cycle and upheavals. In Economics of Technology, ed. O. Granstrand, pp. 397-410. Amsterdam: North-Holland

Zon, H.V. (1996) The Future of Industry in Central and Eastern Europe. Aldershot: Ashgate 
Copyright $\odot 2002$ EBSCO Publishing 